\title{
Allochromatium phaeobacterium sp. nov.
}

\author{
Correspondence \\ Ch. Sasikala \\ r449@sify.com \\ or \\ sasi449@yahoo.ie
}

\author{
T. N. R. Srinivas, ${ }^{1}$ P. Anil Kumar, ${ }^{1}$ K. Sucharitha, ${ }^{1}$ Ch. Sasikala ${ }^{1}$ \\ and Ch. V. Ramana ${ }^{2}$ \\ ${ }^{1}$ Bacterial Discovery Laboratory, Centre for Environment, Institute of Science and Technology, \\ J. N. T. University, Kukatpally, Hyderabad 500 085, India \\ ${ }^{2}$ Department of Plant Sciences, School of Life Sciences, University of Hyderabad, \\ PO Central University, Hyderabad 500 046, India
}

\begin{abstract}
A rod-shaped, phototrophic, purple sulfur bacterium was isolated in pure culture from brackish water near Bheemli, Visakhapatnam, India, in a medium that contained $2 \% \mathrm{NaCl}(\mathrm{w} / \mathrm{v})$. Strain $\mathrm{JA} 144^{\top}$ was Gram-negative and motile. It did not require salt, but tolerated up to $3 \% \mathrm{NaCl}(\mathrm{w} / \mathrm{v})$. Intracellular photosynthetic membranes were of the vesicular type. Bacteriochlorophyll a and carotenoids that probably belonged to the rhodopinal series were present as photosynthetic pigments. Strain $\mathrm{JA} 144^{\top}$ was able to grow photolithoautotrophically, photolithoheterotrophically and photoorganoheterotrophically. It did not require vitamins. Phylogenetic analysis on the basis of $16 \mathrm{~S}$ rRNA gene sequences showed that strain $\mathrm{JA} 144^{\top}$ clustered with species of the genus Allochromatium belonging to the class Gammaproteobacteria. Highest sequence similarities of strain JA144 ${ }^{\top}$ were found with the type strains of Allochromatium vinosum ( $96.7 \%$ similarity), Allochromatium renukae (96.3\%), Allochromatium minutissimum (95.6\%) and Allochromatium warmingii $(89.2 \%)$. Based on 16S rRNA gene sequence analysis and morphological and physiological characteristics, strain JA144 ${ }^{\top}$ is sufficiently different from other Allochromatium species to represent a novel species, Allochromatium phaeobacterium sp. nov.; the type strain is JA144 ${ }^{\top}\left(=\right.$ JCM $14796^{\top}=$ DSM $\left.19781^{\top}\right)$.
\end{abstract}

The genus Allochromatium was created to accommodate some species that had previously been classified as members of the genus Chromatium, based on their genetic distance from Chromatium okenii (Imhoff et al., 1998). At present, the genus Allochromatium comprises four well-described species: Allochromatium vinosum, Allochromatium minutissimum, Allochromatium warmingii and Allochromatium renukae; the latter was characterized in our laboratory (Anil Kumar et al., 2008). In the family Chromatiaceae, suspensions of cells of the following species, which belong to eight genera, are brownish in colour (Imhoff, 2005b): $A$. vinosum, A. minutissimum and Marichromatium gracile (brownish-red); Thiococcus pfennigii and Thiospirillum jenense (orange-brown); Thioalkalicoccus limnaeus and Thioflavicoccus mobilis (yellowish-brown to orange-brown); Rhabdochromatium marinum (beige to orange-brown); and Thiorhodococcus minor (brown-orange). Here, a novel brown phototrophic gammaproteobacterium belonging to the genus Allochromatium is described.

The GenBank/EMBL/DDBJ accession numbers for the 16S rRNA gene sequences of strains $\mathrm{JA} 144^{\top}$ and JA316 are AM712619 and AM901431, respectively.

A supplementary figure showing whole-cell and pigment (acetoneextracted) absorption spectra of strain $\mathrm{JA} 144^{\top}$ is available with the online version of this paper.
Strain JA144 ${ }^{\mathrm{T}}$ was isolated from photolithoheterotrophic enrichments. The sample (anoxic sediment along with water) that yielded strain $\mathrm{JA}_{144^{\mathrm{T}}}$ was collected on 18 March 2007 from a pool of brackish water at Bheemli, Visakhapatnam, India $\left(17^{\circ} 53^{\prime} \mathrm{N} 83^{\circ} 27^{\prime} \mathrm{E}\right)$. The sample had a $\mathrm{pH}$ of 6.8 , a salinity of $10 \%$ and a temperature of $30{ }^{\circ} \mathrm{C}$. The medium used for isolation of strain JA $144^{\mathrm{T}}$ was modified medium of Biebl \& Pfennig (1981) containing $\left(\mathrm{l}^{-1}\right): \mathrm{KH}_{2} \mathrm{PO}_{4}, 0.5 \mathrm{~g} ; \mathrm{MgSO}_{4} \cdot 7 \mathrm{H}_{2} \mathrm{O}, 2 \mathrm{~g} ; \mathrm{CaCl}_{2} \cdot 2 \mathrm{H}_{2} \mathrm{O}$, $0.15 \mathrm{~g} ; \mathrm{NH}_{4} \mathrm{Cl}, 0.68 \mathrm{~g} ; \mathrm{NaCl}, 20 \mathrm{~g}$; yeast extract, $0.5 \mathrm{~g}$; sodium pyruvate, $3 \mathrm{~g}$; micronutrient solution SL7, $1 \mathrm{ml}$; and ferric citrate solution $(0.1 \%, \mathrm{w} / \mathrm{v}), 5 \mathrm{ml}$. Purification and polyphasic taxonomic studies were carried out as described previously (Anil Kumar et al., 2007, 2008).

Individual cells of strain $\mathrm{JA} 144^{\mathrm{T}}$ were rod-shaped (1.0$1.5 \times 2.0-4.0 \mu \mathrm{m})$, multiplied by binary fission and were motile. Electron microphotographs of ultrathin sections of the cells revealed internal membrane structures of a vesicular type. Strain JA144 ${ }^{\mathrm{T}}$ was able to grow photolithoautotrophically [anaerobic conditions, light $(2400 \mathrm{~lx})$, $\mathrm{Na}_{2} \mathrm{~S}_{2} \mathrm{O}_{3} \cdot 5 \mathrm{H}_{2} \mathrm{O}(5 \mathrm{mM})$ and $\mathrm{NaHCO}_{3}(0.1 \%$, w/v)], photolithoheterotrophically [anaerobic conditions, light (2400 lx), $\mathrm{Na}_{2} \mathrm{~S}_{2} \mathrm{O}_{3} .5 \mathrm{H}_{2} \mathrm{O} \quad(5 \mathrm{mM}), \mathrm{NaHCO}_{3} \quad(0.1 \%$, $\mathrm{w} / \mathrm{v})$ and sodium pyruvate $(0.3 \%, \mathrm{w} / \mathrm{v})]$ and photoorganoheterotrophically [anaerobic conditions, light (2400 lx), sodium pyruvate $(0.3 \%, \mathrm{w} / \mathrm{v})]$. Chemolithoautotrophy 
[aerobic conditions, dark, thiosulfate $(5 \mathrm{mM})$ and $\mathrm{NaHCO}_{3}(0.1 \%$, w/v)], chemoorganoheterotrophy [aerobic conditions, dark and sodium pyruvate $(0.3 \%, \mathrm{w} / \mathrm{v})]$ and fermentative growth [anaerobic conditions, dark with fructose $(0.3 \%, \mathrm{w} / \mathrm{v})]$ could not be demonstrated. The organic substrates utilized for photoorganoheterotrophy (Table 1$)$ in the presence of bicarbonate $(0.1 \%, w / v)$ and $0.5 \mathrm{mM} \mathrm{Na}_{2} \mathrm{~S} .9 \mathrm{H}_{2} \mathrm{O}$ included lactate, pyruvate, fumarate, malate and fructose. Organic substrates that could not be utilized by strain $\mathrm{JA} 144^{\mathrm{T}}$ included formate, acetate, propionate, butyrate, valerate, succinate, glucose, ethanol, propanol, glycerol, glycollate, crotonate and Casamino acids. $\mathrm{Na}_{2} \mathrm{~S}_{2} \mathrm{O}_{3} \cdot 5 \mathrm{H}_{2} \mathrm{O}$ was utilized as electron donor (growth was feeble) under photolithoautotrophic conditions by strain $\mathrm{JA} 144^{\mathrm{T}}$, whereas $\mathrm{Na}_{2} \mathrm{~S} .9 \mathrm{H}_{2} \mathrm{O}$, sulfite, elemental sulfur and hydrogen did not support growth. Sodium sulfide, sulfate, sulfite and thiosulfate, and elemental sulfur were utilized as sulfur sources by strain $\mathrm{JA} 144^{\mathrm{T}}$, but thioglycollate and cysteine did not support growth. Strain JA144 ${ }^{\mathrm{T}}$ utilized ammonium chloride, dinitrogen and glutamine as nitrogen sources, but nitrate, nitrite, urea and glutamate did not support growth. Strain $\mathrm{JA} 144^{\mathrm{T}}$ did not require salt, but tolerated up to $3 \%(\mathrm{w} / \mathrm{v}) \mathrm{NaCl}$. The $\mathrm{pH}$ range for growth of strain $\mathrm{JA} 144^{\mathrm{T}}$ was $7.0-8.0$ (optimum $\mathrm{pH}$ 7.5). The temperature optimum was $30{ }^{\circ} \mathrm{C}$ (range $25-35^{\circ} \mathrm{C}$ ). Strain JA144 ${ }^{\mathrm{T}}$ did not require vitamins. The colour of a suspension of photosynthetically grown cells was brown. The wholecell absorption spectrum of strain JA144 ${ }^{\mathrm{T}}$ gave absorption maxima at $374,460,488,518,593,800$ and $857 \mathrm{~nm}$, thus confirming the presence of bacteriochlorophyll $a$; the absorption spectrum for pigments extracted with acetone gave absorption maxima at 448,473 and $506 \mathrm{~nm}$, probably indicating carotenoids of the rhodopinal series (see Supplementary Fig. S1, available in IJSEM Online).

Table 1. Differential characteristics of species of the genus Allochromatium

Taxa: 1 , JA144 ${ }^{\mathrm{T}}$; 2, A. vinosum; 3, A. minutissimum; 4, A. warmingii; 5, A. renukae. Data for taxa 2-4 are from Imhoff (2005a, b); data for A. renukae are from Anil Kumar et al. (2008). Organic substrate utilization was tested during photoorganoheterotrophic growth in the presence of $0.1 \%$ (w/v) bicarbonate and $0.5 \mathrm{mM} \mathrm{Na} 2 \mathrm{~S} .9 \mathrm{H}_{2} \mathrm{O}$. Pyruvate was utilized by all taxa. Ethanol, propanol and glycerol were not utilized by any of the taxa. + , Substrate utilized or present; - , substrate not utilized or absent; \pm , variable; $(+)$, weak growth; NR, not reported. None of the strains required salt and a few marine strains tolerated low concentrations of $\mathrm{NaCl}$. All strains were motile.

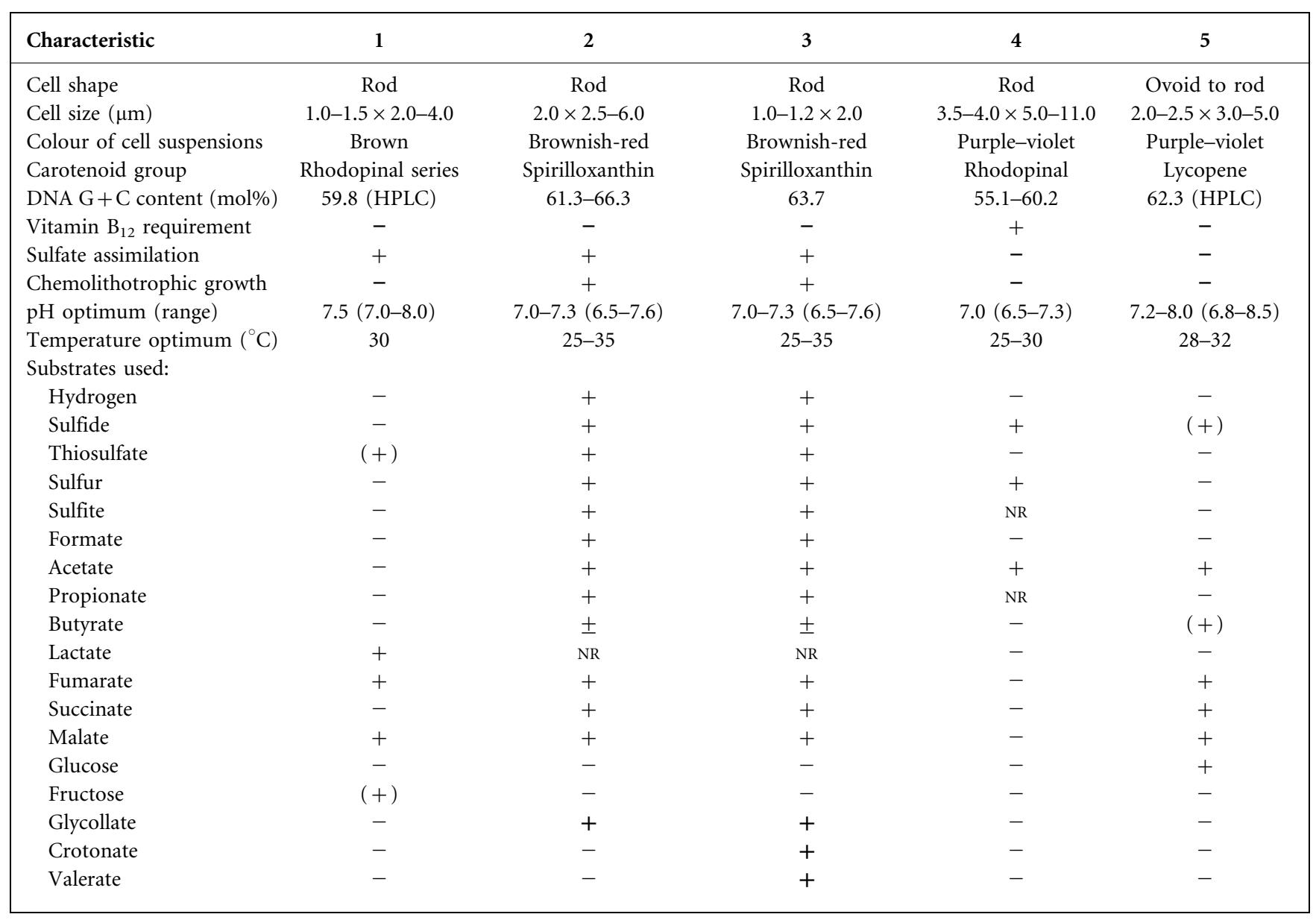


Genomic DNA was extracted and purified according to the method of Marmur (1961) and the DNA G + C content (mol\%) was determined by HPLC (Mesbah et al., 1989). The DNA G + C content of strain JA144 ${ }^{\mathrm{T}}$ was $59.8 \mathrm{~mol} \%$. The phylogenetic relationship of strain $\mathrm{JA}_{144^{\mathrm{T}}}$ to other purple sulfur bacteria was examined by $16 \mathrm{~S}$ rRNA gene sequence analysis. $16 \mathrm{~S}$ rRNA gene sequences were aligned by using the program CLUSTAL_x (Thompson et al., 1997) and the alignment was corrected manually by using BIOEDIT software (Hall, 1999). The evolutionary tree was constructed by using the maximum-likelihood method [DNAML in the PHYLIP package (transition/transversion ratio used was 2.0000)] and the resultant tree topologies were evaluated by bootstrap analysis based on 100 resamplings using the programs SEQBOOT and CONSENSE in the PHYLIP package (Felsenstein, 1989). The data obtained revealed that the novel isolate branched separately, but clustered with type strains of species of the genus Allochromatium and was distinct from members of other genera of purple sulfur bacteria (family Chromatiaceae). Highest sequence similarities of strain JA $144^{\mathrm{T}}$ were found with the type strains of A. vinosum (96.7\%), A. renukae (96.3\%), A. minutissimum (95.6\%) and A. warmingii (89.2\%) (Fig. 1). An unusual signature sequence (TACCTGTCACT) was found between positions 825 and 837 (based on Escherichia coli numbering) in the $16 \mathrm{~S}$ rRNA gene sequence of strain JA144 compared with all other Allochromatium species. In addition to $16 \mathrm{~S}$ rRNA gene sequence dissimilarity, strain JA144 ${ }^{\mathrm{T}}$ could be differentiated clearly from other Allochromatium species based on phenotypic properties (Table 1), thus justifying the description of this strain as a representative of a novel species, Allochromatium phaeobacterium sp. nov. An additional strain, JA316, with $99.8 \%$ 16S rRNA gene sequence similarity to strain JA144 ${ }^{\mathrm{T}}$ (Fig. 1) and possessing other traits of this strain, was isolated from Chilika salt lagoon (Orissa), at Rambha, India ( $\left.19^{\circ} 30^{\prime} \mathrm{N} 85^{\circ} 5^{\prime} \mathrm{E}\right)$.

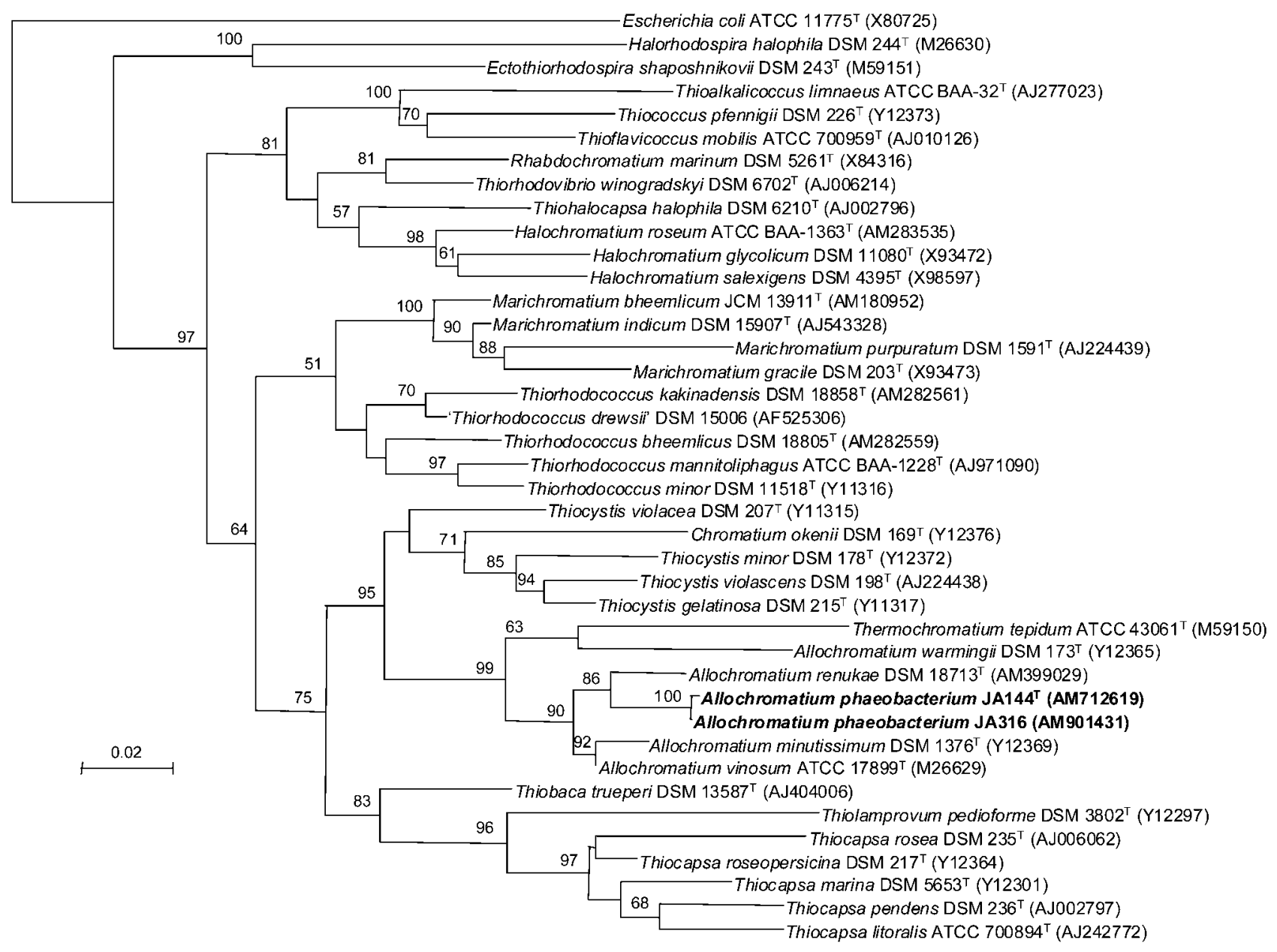

Fig. 1. Evolutionary-distance dendrogram depicting the phylogenetic relationships of strain $J A 144^{\top}$ within the family Chromatiaceae as determined by $16 \mathrm{~S}$ rRNA gene sequence analysis. The dendrogram was constructed by using the program DNAML in the PHYLIP package. Numbers at nodes are bootstrap values; only those over 50 are shown. Bar, 2 substitutions per 100 nt. 


\section{Description of Allochromatium phaeobacterium sp. nov.}

Allochromatium phaeobacterium [phae.o.bac.te'ri.um. Gr. adj. phaeos dark, brown; L. neut. n. bacterium a stick, staff, rod; N.L. neut. n. (nominative in apposition) phaeobacterium the brown rod].

Cells are rod-shaped, $1.0-1.5 \times 2.0-4.0 \mu \mathrm{m}$, motile and divide by binary fission. Growth occurs under anaerobic conditions in the light (photolithoautotrophy, photolithoheterotrophy and photoorganoheterotrophy). Internal photosynthetic membranes are of the vesicular type. The colour of phototrophically grown cultures is brown. The in vivo absorption spectrum of intact cells in sucrose exhibits maxima at 374, 460,488, 518, 593, 800 and $857 \mathrm{~nm}$, thus confirming the presence of bacteriochlorophyll $a$ and carotenoids that are probably of the rhodopinal series. The type strain is mesophilic $\left(30{ }^{\circ} \mathrm{C}\right)$, with a $\mathrm{pH}$ optimum for growth of 7.5. There is no obligatory $\mathrm{NaCl}$ requirement, but up to $3 \%(\mathrm{w} / \mathrm{v}) \mathrm{NaCl}$ is tolerated. Photoorganoheterotrophy with a few organic compounds is the preferred mode of growth. Good carbon sources for growth are pyruvate, fumarate and malate; growth also occurs on lactate and fructose. Chemotrophy is not possible. Growth factors are not required.

The type strain is JA144 ${ }^{\mathrm{T}}\left(=\mathrm{JCM} 14796^{\mathrm{T}}=\mathrm{DSM} 19781^{\mathrm{T}}\right.$ ), isolated from a brackish water body at Bheemli, Visakhapatnam, India. The DNA G $+\mathrm{C}$ content of strain $\mathrm{JA} 144^{\mathrm{T}}$ is $59.8 \mathrm{~mol} \%$ (HPLC).

\section{Acknowledgements}

We thank Professor J. Euzéby for his expert suggestion for the correct species epithet and Latin etymology. Financial assistance received from the Ministry of Earth Sciences, Government of India is acknowledged. P.A.K. and T.N.R.S. acknowledge the CSIR, Government of India, for the award of SR fellowships.

\section{References}

Anil Kumar, P., Sasi Jyothsna, T. S., Srinivas, T. N. R., Sasikala, Ch., Ramana, Ch. V \& Imhoff, J. F. (2007). Marichromatium bheemlicum sp. nov., a non-diazotrophic photosynthetic gammaproteobacterium from a marine aquaculture pond. Int J Syst Evol Microbiol 57, 1261-1265.

Anil Kumar, P., Srinivas, T. N. R., Sasikala, Ch. \& Ramana, Ch. V. (2008). Allochromatium renukae sp. nov. Int J Syst Evol Microbiol 58, 404-407.

Biebl, H. \& Pfennig, N. (1981). Isolation of members of the family Rhodospirillaceae. In The Prokaryotes, pp. 167-273. Edited by M. P. Starr, H. Stolp, H. G. Trüper, A. Balows \& H. G. Schlegel. New York: Springer.

Felsenstein, J. (1989). PHYLIP (phylogenetic inference package), version 3.5.1. Distributed by the author. Department of Genome Sciences, University of Washington, Seattle, USA.

Hall, T. A. (1999). BioEdit: a user-friendly biological sequence alignment editor and analysis program for Windows 95/98/NT. Nucleic Acids Symp Ser 41, 95-98.

Imhoff, J. F. (2005a). Genus II. Allochromatium Imhoff, Süling and Petri 1998b, $1140^{\mathrm{VP}}$. In Bergey's Manual of Systematic Bacteriology, 2nd edn, vol. 2, part B, pp. 12-14. Edited by D. J. Brenner, N. R. Krieg, J. T. Staley \& G. M. Garrity. New York: Springer.

Imhoff, J. F. (2005b). Family I. Chromatiaceae Bavendamm 1924, $125^{\mathrm{AL}}$ emend. Imhoff 1984b, 339. In Bergey's Manual of Systematic Bacteriology, 2nd edn, vol. 2, part B, pp. 3-9. Edited by D. J. Brenner, N. R. Krieg, J. T. Staley \& G. M. Garrity. New York: Springer.

Imhoff, J. F., Süling, J. \& Petri, R. (1998). Phylogenetic relationships among the Chromatiaceae, their taxonomic reclassification and description of the new genera Allochromatium, Halochromatium, Isochromatium, Marichromatium, Thiococcus, Thiohalocapsa and Thermochromatium. Int J Syst Bacteriol 48, 1129-1143.

Marmur, J. (1961). A procedure for the isolation of deoxyribonucleic acid from microorganisms. J Mol Biol 3, 208-218.

Mesbah, M., Premachandran, U. \& Whitman, W. B. (1989). Precise measurement of the $\mathrm{G}+\mathrm{C}$ content of deoxyribonucleic acid by highperformance liquid chromatography. Int J Syst Bacteriol 39, 159-167.

Thompson, J. D., Gibson, T. J., Plewniak, F., Jeanmougin, F. \& Higgins, D. G. (1997). The CLUSTAL_X windows interface: flexible strategies for multiple sequence alignment aided by quality analysis tools. Nucleic Acids Res 25, 4876-4882. 